\title{
EFEKTIFITAS PEMBERIAN MINYAK ZAITUN EKSTRA VIRGIN TERHADAP KADAR GLUKOSA DARAH TIKUS WISTAR JANTAN DENGAN INDUKSI HIPERGLIKEMIA
}

\author{
Sri Lestari Dwi Astuti' ${ }^{1}$ Yeni Tutu Rohimah² \\ 1,2, Kementerian Kesehatan Politeknik Kesehatan Surakarta Jurusan Keperawatan \\ Diterima : 11 Oktober 2018, Disetujui : 26 Oktober 2018 \\ e-mail : yenitutu@yahoo.com
}

\begin{abstract}
Background: The global population of diabetes mellitus tends to increase every year. This is related to the increased of population numbers, lifestyle, increased prevalence of obesity and less physical activity (Smeltzer \& Bare, 2002). Olive oil is a functional diet because it is rich of monounsaturated fatty acids (MUFA), especially oleic acid (70\% $80 \%)$, contains antioxidants and polyphenol compounds. Polyphenols are a-amylase enzyme inhibitors that have function in the breakdown of carbohydrates, so that the level of blood glucose in hyperglycemia can be lowered (Astrawan made, Wresdiyati Tutik, Nasution Nurlayla Amas, 2015). The goal of this study is to examine the effectiveness of extra virgin olive oil to blood glucose level. Method:This study used experimental laboratory study with post test only control group design. The independent variable was the extra virgin olive oil, while the dependent variable was the blood glucose level. The samples were 32 healthy 8 weeks old white male wistar strain rats with the weigh between $180 \mathrm{mg}$ - $200 \mathrm{mg}$. It divided into 3 groups, the negative control group was fed with standard diet, the positive control group was fed with standard diet and $1 \mathrm{ml}$ fructose for 4 weeks, the treatment group was fed with standard diet, $1 \mathrm{ml}$ fructose and 0.5 gr extra virgin olive oil for 4 weeks, on the fifth week the fructose was increased into $4 \mathrm{ml} / d a y$ for the next 4 weeks, on the 52nd day the blood glucose level was checked after it was fasted for 6 hours. The data analysis used t-test and Mann Withney test with $\alpha=0.05$. Result: The blood glucose level average of the positive control group was $309.57 \pm 120.12$, the blood glucose level average of the negative control group was $111.85 \pm 10.57$, the blood glucose level average of the treatment group was $115.12 \pm 12.25$. Conclusion: Giving the extra virgin olive oil can effectively lower the blood glucose level on the male wistar rats.
\end{abstract}

Keywords : Hyperglycemia, Extra Virgin Olive Oil

\section{PENDAHULUAN}

Berdasarkan laporan International Diabetes Federation tahun 2015, jumlah populasi Indonesia yang terkena diabetes mencapai 9,1 juta orang dan $53 \%$, penderita diabetes di Indonesia tidak menyadari bahwa dirinya terkena diabetes. Pada tahun 2011, Indonesia berada pada peringkat ke-10 dunia untuk kasus diabetes dengan jumlah penderita 7,2 juta jiwa dan naik pada tahun 2013 menjadi peringkat ke-7 dengan jumlah penderitasebanyak 8,5 juta jiwa. Tahun 2014, Indonesi berada pada peringkat ke5. Peningkatan penderita dari tahun ke tahun membuktikan bahwa diabetes 
millitus merupakan masalah kesehatan di masyarakat yang serius bila tidak dilakukan upaya perubahan pola hidup sehat pada penderita (Shahab Alwi, 2006).

Penatalaksanaan Diabetes Melitus dikenal 4 pilar utama pengelolaan yaitu: penyuluhan, perencanaan makan, latihan jasmani, dan obat hipoglikemik. Terapi gizi merupakan komponen utama keberhasilan penatalaksanaan diabetes. Minyak zaitun merupakan merupakan pakan yang fungsional karena kandungannya kaya dengan monounsaturated fatty acids (MUFA) terutama asam oleat (70\%\%-80\%), mengandung antioksidan dan senyawa polifenol. Polifenol dari tumbuhan memiliki berbagai potensi yang berguna bagi kesehatan dan sebagai agen hipoglikemik. Polifenol merupakan inhibitor enzim $\alpha$-amilase yang berfungsi dalam pemecahan karbohidrat, dengan adanya inhibisi pada enzim ini, proses pemecahan dan absorbsi karbohidrat akan terganggu, sehingga kadar glukosa darah pada hiperglikemia dapat diturunkan (Astrawan made,Wresdiyati Tutik, Nasution Nurlayla Amas, 2015).

\section{METODE PENELITIAN}

Jenis penelitian yang digunakan adalah eksperimen laboratorik dengan rancangan post test only control group design (Murti Bhisma,2013). Variabel Bebas : pemberian minyak zaitun ekstra virgin, Variabel Terikat : kadar glukosa darah. Sampel pada penelitian ini adalah tikus wistar jantan umur 8 minggu dengan berat badan antara $180 \mathrm{mg}-200$ mg dengan kondisi sehat. Cara penelitian Adaptasi kepada tikus diberikan dengan perawatan dikandang supaya dapat bergerak bebas dan tidak stress juga diberikan pakan standar dalam $1 \mathrm{mg}$. Setelah 1 minggu tikus dibagi secara random ke dalam 3 kelompok yaitu kelompok kontrol negatif $\left(\mathrm{K}_{1}\right)$ berjumlah 9 ekor, kelompok kontrol positif $\left(\mathrm{K}_{2}\right) 8$ ekor, kelompok Perlakuan (P) 18 ekor. Kelompok control negatif (K1) dibeberikan pakan standar dan minum standar selama $7 \mathrm{mg}$. Kelompok kontrol positif diberikan pakan standar dan diberikan air minum berupa larutan fruktosa $55 \%$ sebanyak $1 \mathrm{ml}$ yang diencerkan dengan $2 \mathrm{ml}$ aquades untuk menginduksi kondisi hiperglikemia selama $4 \mathrm{mg}$. Fruktosa diberikan dengan disondekan ke dalam lambung. Kolompok perlakuan (P) diberikan pakan dan diberikan minum berupa fruktosa $55 \%$ sebanyak $1 \mathrm{ml}$ dan ekstak virgin olive oil 0,5 gr yang diencerkan dengan $2 \mathrm{ml}$ aquades selama $4 \mathrm{mg}$. Fruktosa dan minyak zaitun ekstrak virgin diberikan dengan disondekan ke dalam lambung. Pada minggu ke 5 sampai minggu ke 8 kelompok control negative diberikan pakan standar dan minum standar berjumlah 9 ekor, kolompok control positif diberikan pakan standar dan diberi minum fruktosa $55 \% 4 \mathrm{ml}$ berjumlah 7 ekor dan kelompok perlakuan diberi pakan standar serta minum fruktosa $55 \% 4 \mathrm{ml}$ dan minyak zaitun 0,5 gr yang diencerkan dengan aquades $2 \mathrm{ml}$ berjumlah 16 ekor. Pengambilan data berupa sampel darah untuk pemeriksaan kadar glukosa darah dilakukan pada hari ke 60 pada kelompok control negative (K1), kelompok control positif (K2) dan kelompok perlakuan (P) melalui pembuluh darah periper bagian ekor menggunakan alat ukur Easy Touch. Sebelum dilakukan pengambilan darah tikus dipuasakan selama 6 jam. 


\section{HASIL PENELITIAN}

Tabel 1. Rerata kadar glukosa darah tikus wistar

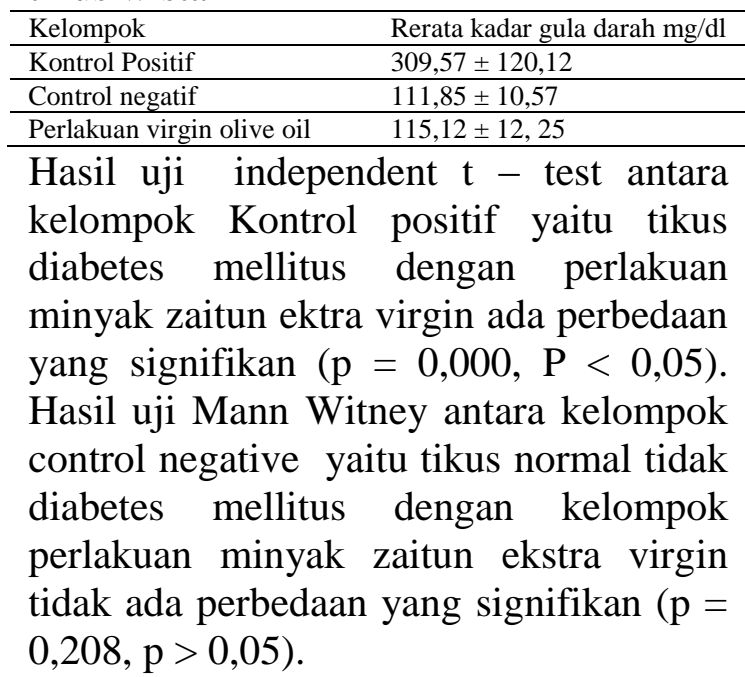

\section{PEMBAHASAN}

Diabetes millitus tipe 2 yaitu tipe tidak tergantung insulin sering kali disebabkan karena adanya gangguan resistensi hormone insulin sehingga mengakibatkan menurunnya sensitivitas reseptor insulin yang berada pada membran sel, dan pada akhirnya bekurangnya kegiatan metabolisme insulin dalam sel yang berakibatkan respon jaringan berkurang sehingga pada penderita diabetes mellitus tidak dapat merubah glukosa menjadi glikogen yang diseimpan di dalam otot dan hati sehingga untuk mendapatkan tenaga dilakukan pemecahan adoposa yang mengakibatkan terjadinya pemecahan asam lemak bebas di dalam darah yang memicu terjadinya gannguan fluiditas membrane sel akibat ruang hidrofilik pada membrane sel berkurang. MUFA yang terdapat dalam minyak zaitun ekstra virgin memiliki efek protektif dan promotif terhadap sel beta pancreas. Disfungsi pancreas dapat ditekan oleh
MUFA dengan cara mengurangi kerusakan beta pankras dan memicu neogenesis sel beta (Alonso et al. 2005).

Minyak zaitun yang mengandung monounsaturated fatty acids (MUFA), terutama asam oleat (70\%\%-80\%), mengandung antioksidan dan senyawa polifenol sebagai agen hipoglikemik yang merupakan inhibitor enzin enzim $\alpha$ amilase yang berfungsi dalam pemecahan karbohidrat, dengan adanya inhibisi pada enzim ini, proses pemecahan dan absorbsi karbohidrat akan terganggu, sehingga kadar glukosa darah pada hiperglikemia dapat diturunkan, serta terjadi penurunan lemak perut secara signifikan. Pada penderita diabetes millitus mengalami penurunan resistensi insulin dan jumlah hormon adiponektin meningkat. Adiponektin adalah hormon menguntungkan yang diproduksi dan disekresikan oleh sel-sel lemak (adipocytes), yang berperan dalam mengatur gula dan metabolisme lemak, mencegah resistensi insulin, dan memiliki efek anti-inflamasi pada sel-sel yang melapisi dinding pembuluh darah (Sugiyanta. 2012).

Hasil dari penelitian yang dirilis dalam jurnal ilmiah Diabetes Care menunjukkan bahwa mengonsumsi minyak zaitun sebagai diet tinggi lemak sehat telah terbukti mengurangi risiko diabetes tipe 2 pada $50 \%$ dibandingkan dengan mereka yang melakukan diet rendah lemak. Seseorang dengan obesitas yang memiliki memiliki resistensi insulin berada pada risiko tertinggi untuk diabetes dan komplikasi jantung. Diet tinggi lemak sehat dengan minyak zaitun memberi hasil setelah 4 tahun. Sekitar 17,9 \% dari koresponden dengan obesitas yang mengikuti diet rendah lemak mengembangkan risiko diabetes tipe 2 . 
Dan 52 persen dari koresponden yang diet tinggi lemak tak jenuh rantai tunggal minyak zaitun terhindar dari risiko diabetes tipe 2, sehingga dapat disimpulkan bahwa diet kaya minyak zaitun dapat mencegah munculnya diabetes tipe 2 dengan perbaikan kadar gula darah, menurunkan resistensi insulin dan menyeimbangkan kadar lipid dalam darah (Madigan, Claire et al. 2000).

Senyawa polifenol dalam minyak zaitun merupakan hidroksitirosol. Senyawa ini membantu melindungi selsel yang melapisi pulau langerhans dari kerusakan akibat reaksi oksigen yang berlebihan. Hidroksitirosol pada minyak zaitun membantu melindungi dinding selsel dari kerusakan dengan meningkatkan sistem pertahanan antioksidan. Hidroksitirosol sebagai molekul unik yang membantu dinding sel agar tetap kuat (Alonso et al. 2005).

Senyawa polifenol dalam minyak zaitun merupakan hidroksitirosol. Senyawa ini membantu melindungi selsel yang melapisi pulau langerhans dari kerusakan akibat reaksi oksigen yang berlebihan. Hidroksitirosol pada minyak zaitun membantu melindungi dinding selsel dari kerusakan dengan meningkatkan sistem pertahanan antioksidan. Hidroksitirosol sebagai molekul unik yang membantu dinding sel agar tetap kuat (Alonso et al. 2005).

Pada penderita diabetes millitus terjadi pemecahan adipose yang meningkat yang mengakibatkan terjadinya peningkatan asam lemak bebas dalam darah, sehingga terjadi kekurangan ruang hidrofilik pada membran sel yang akhirnya menngakibatkan terjadinya gangguan fluiditas membaran sel. Gangguan fluidatas membaran akan mempersulit lokasi dari protein reseptor kunci, yaitu $\mathrm{G}$ dan protein kinase c alpha (PKC $\alpha$ ), dan juga menurunkan sensitivitas protein kunci terhadap hormone insulin. Keadaan ini mengakibatkan menurunnya aksi metabolisme insulin dalam sel yang pada akhirnya menurunkan respon jaringan. Kandungan MUFA yang terdapat dai dalam minyak zaitun ekstra virgin dapat mengubah komposisi asam lemak membrane sel target sehingga dapat mempengaruhi fungsi reseptor insulin. Perubahan komposisi asam lemak akan berakibat pada proses transmisi sinyal yang melibatkan protein reseptor kunci yaitu sub unit $G$ protein dan protein kinase alfa $(\mathrm{PKC} \alpha)$. Mufa mengakibatkan terjadi perubahan komposisi membrane sel menjadi lebih kaya asam lemak yang lebih kaya tipe cis. Asam lemak tipe cis membantu substitusi komponen ekor pada membrane sehingga diantara gugus kepala membrane lebih banyak terbentuk ruangan yang lebih luas yang bersifat hidrofilik dan akibatnya fluiditas membrane meningkat. Peingkatan perluasan ruang membrane kepala dan peningkatan fluiditas membrane memprofokasi lokalisasi dan dan aktivitas dari sub unit $\mathrm{G}$ protein dan dan $\mathrm{KPC} \alpha$ yang merupakan reseptor kunci sehingga mempermudah keduanya mencapai lokasi permukaan membrane dan sensitivitas serta meningkatkan sensitivitas sinyal keduanya (Juan A. et al.. 2007).

\section{KESIMPULAN DAN SARAN}

Pemberian minyak zaitun ekstra virgin effektif menurunkan kadar glukosa darah tikus winstar jantan. Kepada masyarakat umum yang memiliki nilai glukosa darah dalam batas normal untuk mengcegah terjadinya diabetes tipe 2 sebaiknya untuk mengkonsumsi minyak 
zaitun ekstra virgin. Kepada penderita diabetes millitus tipe 2 sebaiknya diet yang dilaksanakan menambahkan asupan asam lemak essensial yang berasal dari minyak zaitun ekstra virgin.

\section{DAFTAR RUJUKAN}

Alonso et al. 2005. Monounsaturated Fatty Acids, Olive Oiland Blood Pressure:Epidemiological,

Clinical and Experimental Evidence. Public Health Nutrition: 9(2), 251-257, DOI: 10.1079/PHN2005836.

Alwi Shahab (2006). Diagnosis dan penatalaksanaan Diabetes Mellitus. Subbagian metabolic Bag. Ilmu Penyakit dalam FK Unsri. Palembang.

Juan A. et al.. 2007. A MUFA-Rich Diet Improves Posprandial Glucose, Lipid and GLP-1 Responses in Insulin-Resistant Subjects. Spain: American college of mutrition

Madigan, Claire et al. 2000. Dietary Unsatturated Fatty Acid in type 2 diabetes: Higher Levelsof post Prandial Lipoprotein on a Linoleic Acid-Rich Sunflower Oil Diet Compared with an Oleic Acid-Rich Olive Oil Diet. Diabetes care 23:1472-1477

Murti Bhisma (2013). Desain dan Ukuran Sampel Untuk Penelitian Kuantitatif dan Kualitatif di Bidang Kesehatan. Gadjah Mada University Press. Yogyakarta.

Sugiyanta. 2012. "Pengaruh Minyak Zaitun Terhadap Kadar GKukosa darah. [Internet]. [cited 2017 juni 24] Available from : http://repository.unej.ac.id/bitstre am/handle/123456789/237/PENG
ARUH\%20MINYAK\%20ZAITUN.p

$d f ;$ sequence $=1$ 